\title{
The effect of zearalenone mycotoxins at late gestation days on the development and reproductive organs
}

\author{
YULIA IRNIDAYANTI" \\ Department of Biology, Faculty of Mathematics and Natural Sciences, State University of Jakarta. Jl. Pemuda No. 10 Rawamangun, East Jakarta 13220, \\ Jakarta, Indonesia. Tel: +92-21-4894909. email: irnidayanti@yahoo.com
}

Manuscript received: 30 December 2011. Revision accepted: 6 February 2012.

\begin{abstract}
Irnidayanti Y. 2012. The effect of zearalenone mycotoxins administration at late gestation days on the development and reproductive organs of mice. Nusantara Bioscience 4: 1-5. Zearalenone was injected subcutaneously with a dose of $30 \mathrm{mg} / \mathrm{kg}$ body weight to pregnant mice on the 13 to 16 days. Control was given only sesame oil. Control and treated mice were killed on day 18 of gestation by cervical dislocation. Observations of maternal body weight, reproductive performance, external and internal malformation were conducted. Histological analysis of fetal ovaries, uterus, and testes was also done. The results revealed that administration of zearalenone to mice at late gestation was not teratogenic. Zearalenone caused a tendency that the primordial follicles and follicular cells relatively decreased in number and the number of the degenerate primordial follicle relatively increased. Effects of zearalenone on the uterus caused a significant increase in the height of lumen epithelial cells and in the thickness of the uterine wall were significant. The lamina propria and myometrium started to differentiate. In the male fetus, zearalenone caused a tendency to decrease in number of the Leydig cells.
\end{abstract}

Keywords: zearalenone, primordial follicle, follicle cells, uterus, Leydig cells.

\begin{abstract}
Abstrak. Irnidayanti Y. 2012. Pengaruh pemberian mikotoksin zearalenon pada umur kebuntingan lanjut terhadap perkembangan dan organ reproduksi mencit.Nusantara Bioscience 4: 1-5. Zearalenon diberikan pada induk mencit bunting pada umur kebuntingan 13 sampai dengan 16 hari secara subkutan. Mencit kontrol hanya diberi minyak wijen. Mencit kontrol dan perlakuan dibunuh pada umur kebuntingan 18 hari secara dislokasi leher. Pengamatan dilakukan terhadap berat badan induk, penampilan reproduksi, kelainan eksternal dan internal. Pengujian juga dilakukan terhadap histologis ovarium fetus, uterus fetus dan testis fetus. Hasil penelitian menunjukkan bahwa pemberian zearalenon kepada mencit pada umur kebuntingan lanjut, tidak bersifat teratogenik. Zearalenon cenderung menyebabkan folikel-folikel primordial dan sel-sel folikel primordial, relatif jumlahnya menurun dan jumlah folikel primordial yang berdegenerasi relatif meningkat. Pemberian zearalenon menyebabkan bertambah tingginya sel-sel epitel pada lumen uterus, secara signifikan dan bertambahnya ketebalan dinding uterus secara signifikan Lamina propria dan miometrium sudah mulai berdifferensiasi. Pada fetus jantan, zearalenon cenderung menyebabkan penurunan jumlah sel-sel Leydig.
\end{abstract}

Kata kunci: zearalenone, folikel primordial, sel-sel folikel, uterus, sel Leydig.

\section{INTRODUCTION}

Zearalenone is a natural mycotoxin produced by Fusarium roseum and grows on grain stored in a very high humid (Stob et al. 1962; Christensen et al. 1965; Chang et al. 1979). It is a secondary metabolite produced by Fusarium, associated with hyperestrogenism syndrome and bleeding in farm animals (Mirocha et al. 1976). Mycotoxin has a trivial (Urry et al. 1966) name, zearalenone and its trade name, RAL ( $\beta$-resorcylic acid lactone). Initial information about the chemical structure of zearalenone was expressed as enantiomorph of 6-(10- hydroxy-6-oxotrans-1-undecenyl)- $\beta$-resorcylic acid lactone, with a chemical formula of $\mathrm{C}_{18} \mathrm{O}_{5} \mathrm{H}_{22}$ (Urry et al. 1966). Zearalenone can absorb ultraviolet light with wavelengths of 314,274 , and $236 \mu \mathrm{m}$, has a melting point at $163-165^{\circ} \mathrm{C}$, has a molecular weight of 318 and has the character of blue-green fluorescence (Mirocha et al. 1967).
Concern of toxic metabolites produced by fungus began when an investigation found evidence of an association between aflatoxin and carcinogenesis in humans (Shank et al. 1971). Hidy et al. (1977) and Hobson et al. (1977) reported that zearalenone in primates can cause keratinization in vaginal epithelium, inhibit ovulation, inhibit the occurrence of implantation and suppress gonadotropin secretion. Corn contaminated by mold is a type of grain most often found in hyperestrogenism cases in pigs. One to $17 \%$ of contaminated corn samples turned out to contain zearalenone (Bennett and Shotwell 1979). Reports from McNutt et al. 1928 showed that the occurrence of estrogenic syndromes such as vulvar and vaginal bleeding posterior part, associated with consumption of moldy feed. Although zearalenone does not have chemical structures such as steroids, but this substance has potent trophic activity on the uterus of some animals (Ueno et al. 1974). Unique chemical structure of zearalenone can interact directly with estrogen receptors in 
the body and cause biological and biochemical responses such as that caused by natural estrogen, estradiol (Katzenellenbogen et al. 1979).

Fusarium grows in humid conditions and optimal temperature for infection is $20-25^{\circ} \mathrm{C}$, and cold temperatures $\left(8-10^{\circ} \mathrm{C}\right)$ is required to produce an optimal zearalenone (Christensen and Kaufmann 1969). Fusarium can contaminate grain stored in a very high humid room (Stob et al. 1962; Christensen et al. 1965). Corn contaminated by the fungus is a type of grain most often found in hyperestrogenism cases in pigs. Not only in corn seeds, but zearalenone is also found in barley. Animal feed containing contaminated material by fungus can cause losses to farmers (Bannett and Shotwell 1979), because it can cause some types of reproductive disorders, such as infertility, persistent estrus, pseudopregnancy, decreased fertility, reduced size of puppies, malformations, hiper-estrogenism in young animals and the possibility of resorption of embryos (Chang et al. 1979). Therefore, the objective of this study was to investigate whether zearalenone affect fetal development of mice, differentiation and development of reproductive system, if the dams were given zearalenone subcutaneously at a dose of $30 \mathrm{mg} / \mathrm{kg}$ body weight on gestation 13 to 16 days

\section{MATERIALS AND METHODS}

Animals used in these experiments were mice (Mus musculus) Swiss Webster taken from Laboratory Animal Care, Department of Pharmacy, ITB. The animals were kept in cages, Department of Biology, ITB. Male and female mice were kept in separate cages. Each virgin female mouse which was in a state of estrus, 11-12 weeks old, with a body weight of 23.5 to 29.5 grams were mated with male mice of the same age. Matings of male mice with females were conducted at 17.00. The occurrence of vaginal plug in the next morning was a sign of copulation and that day was designated as gestation day zero. Then the female mice were weighed and separated from the males.

Zearalenone used in this study was made in Makor Chemical POB 6570, Jerusalem, Israel. Zearalenone crystals were dissolved in sesame oil. Zearalenone solution was injected daily, subcutaneously in mice at gestation of 13 to 16 days. The volume of injection for the control and treated mice were $0.1 \mathrm{ml} / 10 \mathrm{~g}$ body weight, with a dose of $30 \mathrm{mg} / \mathrm{kg}$ body weight. Control mice were only given sesame oil. Mice were killed by cervical dislocation at gestation 18 days, then observations were done to the parent body weight of mice, reproductive performance, external and internal abnormalities. To detect internal malformations, half of live fetuses were fixed in Bouin solution. Then, the mice were dissected and the cardiovascular, urogenital organs, lens, retina, nasal cavity, and cerebrum were observed (Taylor 1986).

Histological observations were done with paraffin method (Sutasurya 1985). Fetal urogenital organs were fixed in bouin solution for 24 hours. Then, staining with Hematoxylin-Eosin was done and sliced with $8 \mu \mathrm{m}$ thick. In histological preparations of ovarian, the shape and differentiation of muscle layer of uterine epithelial cells were observed. The thickness of epithelium and the uterine wall without epithelium was measured. Testicular histological observations were conducted by counting the number of seminiferous tubules, spermatogonia cells, and Leydig cells. For each animal, the average number of slide readings was $15-20$.

"Wilcoxon's rank sum test" was used to analyze nonparametric data, such as the percentage of intrauterine death, the percentage of live fetuses, the percentage of external and internal malformations. Parametric data, such as thickness of epithelium of the uterus, the uterine muscle wall thickness, number of seminiferous tubules, spermatogonia, and Leydig cell number were examined by analysis of variance at the level of $95 \%$ (Steel and Torrie 1981).

\section{RESULTS AND DISCUSSION}

Observations on mice body weight were listed in Table 1. The injection of zearalenone with a dose of $30 \mathrm{mg} / \mathrm{kg}$ body weight on 13 to 16 days of gestation had no effect on body weight and the weight of the dams. It can be concluded that zearalenone given at a dose of $30 \mathrm{mg} / \mathrm{kg}$ body weight at late gestation was not toxic to mice. There were no external abnormalities, but there was bleeding in some fetuses. Similar result was also found in the study by Mirocha et al. (1976), that states the metabolites produced by Fusarium zearalenone could cause bleeding in livestock.

Table 1. Weight state of mice that were given zearalenone with a dose of $30 \mathrm{mg} / \mathrm{kg}$ body weight at gestation days 13 to 16 .

\begin{tabular}{|c|c|c|c|c|c|}
\hline $\begin{array}{c}\text { Gestation } \\
\text { (days) }\end{array}$ & $\begin{array}{c}\text { Dose of } \\
\text { zearalenone } \\
(\mathbf{m g} / \mathbf{k g ~ b b})\end{array}$ & $\begin{array}{l}\Sigma \text { Parent } \\
\text { observed }\end{array}$ & $\begin{array}{c}\text { Body weight parent at } \\
\text { GD-0 (g) } \\
\quad \times \pm \text { sem } \\
\end{array}$ & $\begin{array}{c}\text { Body weight parent } \\
\text { at GD-18 (g) } \\
\times \pm \text { sem }\end{array}$ & $\begin{array}{c}\text { Increase of body weight } \\
\text { at } \\
\text { GD-18 (g) } \\
\times \pm \text { sem } \\
\end{array}$ \\
\hline \multirow{2}{*}{13 to 18} & 0 & 10 & $26.18 \pm 0.44$ & $44.04 \pm 1.29$ & $18.17 \pm 0.66$ \\
\hline & 30 & 10 & $27.86 \pm 0.59$ & $46.07 \pm 1.35$ & $18.21 \pm 0.96$ \\
\hline
\end{tabular}




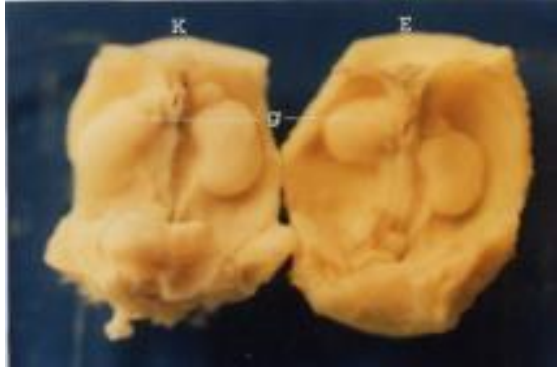

1

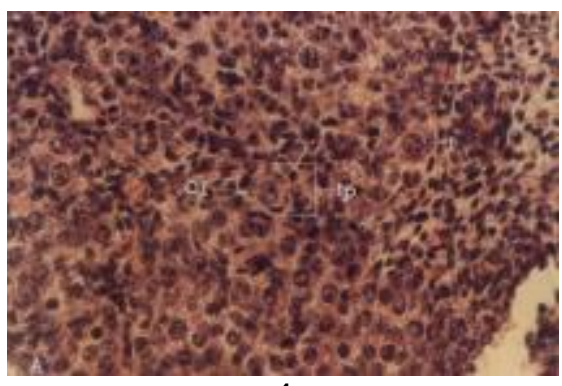

4

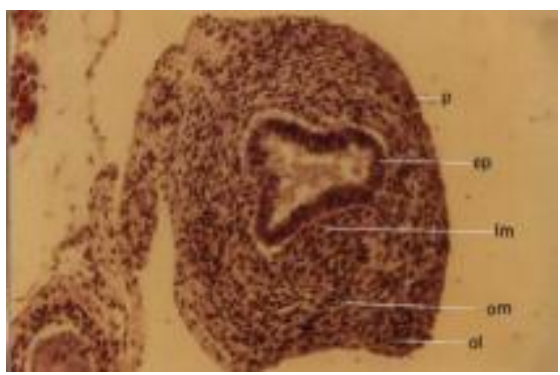

7

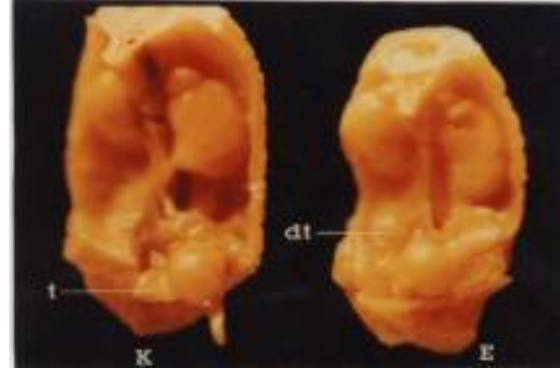

2

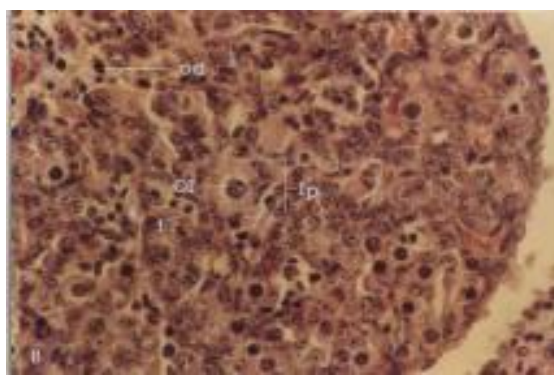

5

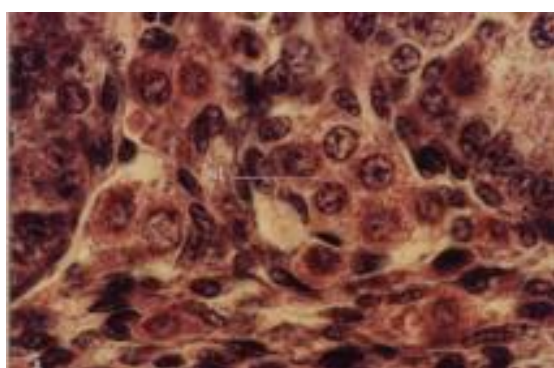

8

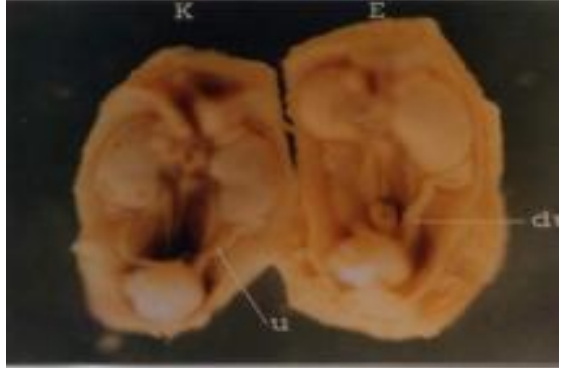

3

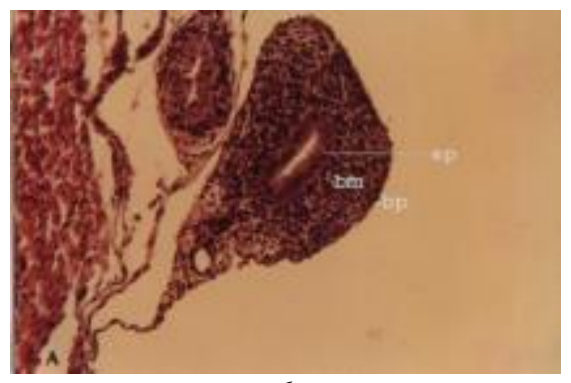

6

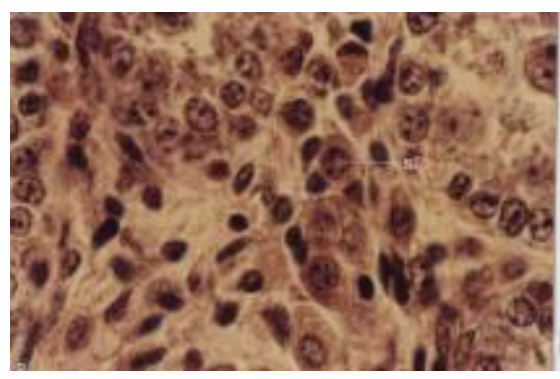

9

Figure 1. Right kidney is smaller than the left kidney in fetal mice 18 days of age zearalenone with pregnant mice that was given a dose of $30 \mathrm{mg} / \mathrm{kg}$ body weight at age gestation 13 to 16 day (Magnification 8x). K: Control, E: treatment Smaller right kidney (g).

Figure 2. Dilatation of the uterus at the age of 18 days fetal mice from a given parent zearalenone with a dose of $30 \mathrm{mg} / \mathrm{kg}$ body weight at gestation 13 to 16 days (magnification 8x). C: Control E: Treatment Dilatation of the uterus (du), uterus (u).

Figure 3. Dilatation of the uterus at the age of 18 days fetal mice from a given parent zearalenone with a dose of $30 \mathrm{mg} / \mathrm{kg}$ body weight at gestation 13 to 16 days (magnification 8x). C: Control E: Treatment Dilatation of the uterus (du), uterus (u).

Figure 4. Cross section fetal ovaries of mice aged 18 days, from the parent who zearalenone given at a dose of $0 \mathrm{mg} / \mathrm{kg}$ body weight at gestation 13 to 16 days. (magnification 400x) Primary oocytes (OI), primordial follicle (fp), follicular cells (f), stroma (s). Degenerating oocytes (od).

Figure 5. Cross section fetal ovaries of mice aged 18 days from the parent who was given zearalenone a dose of $30 \mathrm{mg} / \mathrm{kg}$ body weight at gestation 13 to 16 days (magnification 400x). Primary oocytes (OI), follicle primordial (fp), follicular cells (f), stroma (s), oocytes degenerating (od).

Figure 6. Cross-section of the uterine fetal mice aged 18 days, from the parent who was given zearalenone with $0 \mathrm{mg} / \mathrm{kg}$ body weight at gestation 13 to 16 days, magnification 200x. Epithelium (ep), will myometrium (bm), primordium perimetrium (bp)

Figure 7. Cross-section of the uterine fetal mice aged 18 days, from the parent who was given zearalenone with $0 \mathrm{mg} / \mathrm{kg}$ body weight at gestation 13 to 16 days, magnification 200x. Epithelium (ep), lamina propria (lm), circular muscle (om), longitudinal muscle (ol), perimetrium (p).

Figure 8. Cross-section of fetal testes of mice aged 18 days from the parent who was given zearalenone with $0 \mathrm{mg} / \mathrm{kg}$ body weight at gestation 13 to16 days, magnification 400x. Leydig cells (sL)

Figure 9. Cross-section of fetal testes of mice aged 18 days from the parent who was given zearalenone with $30 \mathrm{mg} / \mathrm{kg}$ body weight at gestation 13 to 16 days, magnification 400x. Leydig cells (sL). 
Various abnormalities of the internal organ development in fetuses at the age of 18 days were found, such as the right kidney is smaller than the left one. This abnormality was found in the fetus from the mice of treatment (Figure 1) as well as in control fetuses, and Statistically, there was no significant in percentage of this abnormality in between treatment and control. Therefore, we suspect that these incidents occurred spontaneously.

Bilateral testicular descendency was only found in fetal treatment (Figure 2). Normal mice fetus has a pair of testicles that are located on the right and left of vesica urine (Taylor 1986). The failure of the testes to descend from the abdominal cavity to the scrotum was caused by the failure of migration of testes into the pelvic cavity. Descendency of bilateral testes was not found in control, and it was found only in $20 \%$ on treatment group. There was no significant difference between treatment and control. Nevertheless, zearalenone was likely to inhibit testicular descendences.

Dilatation of the uterus is a reproductive tract abnormality, which was found in this study. The uterus is a major target organ of zearalenone in mice (James and Smith 1982). Dilatation of the uterus in this study was $27.50 \%$ and was not found in control. Dilatation of the uterus is caused by zearalenone, as supported by histological observation data (Figure 3 ).

The histological structure of fetal ovaries of treated mice showed a difference with that of control. Fetal ovaries of mice at the age of 18 days consisted of the medulla and cortex, but the boundary on the second part was not clear on the control fetuses (Figure 4). While in the fetal ovary slice of treated mice, the medulla and cortex boundary was already beginning to seem (Figure 5). In addition, primordial follicles were also found, but relatively fewer in number than of the control and degenerate primordial follicles were relatively more numerous than those in the controls (Figure 6 and 7). This is consistent with the results of research by Yasuda et al. (1985), which used ethinyl estradiol in mice. In normal fetal mice, a number of follicle cells surrounding the oocyte contribute to prevent the process of egg follicle atresia (Yasuda et al. 1986). According to Rugh (1968), follicle cells begin to form on day 13 of gestation. At the time of follicle formation begins, then the secretion of estrogen begins (Yasuda et al. 1987). Therefore, the activity of ethinyl estradiol same with activity zearalenone. The results were also supported by Abid et al. (2004) that zearalenone reduces cell viability and inhibits DNA synthesis and it induced DNA damage and increase MDA formation. Because of the maximal cell population in follicles are granulosa cells, which play an essential role in the development and maturation of follicle (Zhu et al. 2011), global suppression of oocytes transcriptional activity and the induction of oocytes meiotic and cytoplasmic maturation (Rodgers and Irving Rodgers 2010; Sue et al. 2009). Moreover, granulosa cells are involved in ovarian local microenvironment control system, whereas apoptosis of granulosa cells may lead to follicular atresia. Therefore it can be concluded, that administration of zearalenone may interfere with interactions between follicle cells with the oocyte, so that many of follicular cell atresia.

In cross sections of fetal uterine of control, the walls were composed of epithelial layer limiting cylindrical lumen, primordia myometrium, and perimetrium which is the outermost layer (Figure 6). While on the cross-section of fetal uterine of treatment, the uterine wall consisted of a layer of cylindrical epithelium which were significantly higher than that of controls, lamina propria had already been taking shape; myometrium had already been differentiated into the circular muscle layer, longitudinal muscle layers were beginning to appear; new perimetrium showed a single layer of epithelium (Figure 7). The uterine wall thickness of fetuses of treated mice $(98.53 \mu \mathrm{m})$ was significantly greater than that of controls $(64.65 \mu \mathrm{m})$. Similarly, a thick layer of the uterine without epithelium also significantly. Thus it can be concluded that administration of zearalenone can stimulate differentiation of the uterus lining fetal mice at the age of 18 days, as well as the lamina propria and circular muscle layer, which is beginning to look. The results of this study were also supported by the results of research by Ueno et al. (1974) that zearalenone stimulates cell proliferation and mitotic cells of the uterine muscle. Zearalenone has activity that also the same activity with of $\beta$-estradiol, its can bind estrogen receptors and involved in estrogen-mediated event. Zearalenone has a potent estrogenic activity and it causes several physiological alterations of the reproductive tract (Hidy et al. 1977).

Histological structure of testes of treatment showed differences from that of the control. Testicular crosssections of control fetuses (Figure 8) consisted of interstitial tissue and seminiferous compressed tubules, without lumen. Whereas, the seminiferous tubules in testes of treatment had started to form lumen (Figure 9). In control of fetal testis interstitial tissue, Leydig cell group was composed of five to six cells. While in the testis of treatment, Leydig cell group was composed of two to three cells, which was significantly smaller amount than of control. This situation is supported by the results of Yasuda et al. (1986), that the target organ of ethinyl estradiol is Leydig cell nucleus, which can disrupt the function of DNA in the process of cell proliferation. From the results of this research, it can be concluded that zearalenone affects the number of Leydig cells. Zearalenone gave at 13 to 16 days of gestation, possibly disrupts the function of DNA in the process of cell proliferation, because the process of mitosis of mesenchymal cells that differentiate into Leydig cells occur in fetuses at the age of 13 to 15 days and decreases at 18 days old fetuses.

\section{CONCLUSION}

From this research, it can be concluded that zearalenone given at late gestation, is non-teratogenic, but is more estrogenic in a way to accelerate the development of the uterus. Apparently, zearalenone disrupts ovarian 
development process. In male fetus zearalenone a relative decrease in the number of Leydig cells.

\section{REFERENCES}

Abid-Essefi S, Ouanes Z, Hassen W, Baudrimont I, Creppy E, Bacha H. 2004. Cytotoxicity, inhibition of DNA and protein syntheses and oxidative damage in cultured cells exposed to zearalenone. Toxicol in Vitro 18 (4): 467-474.

Bannett GA, Shotwell OL. 1979. Zearalenone in cereal grains. J Amer Oil Chem 56: 812-819.

Chang K, Kurtz HJ, Mirocha CJ. 1979. Effects of the mycotoxin zearalenone on swine reproduction. Am J Vet Res 40: 1260 - 1267.

Christensen CM, Nelson GH, Mirocha CJ. 1965. Effect on the white rat uterus of a toxic substance isolated from Fusarium. Appl Microbiol 13: 653-659.

Christensen CM, Kaufmann HH. 1969. Grain storage: The role of fungi in quality loss. University of Minnesota Press, Minneapolis, Minnesota.

Hobson W, Bailey J, Fuller GB. 1977. Hormone effects of zearalenone in nonhuman primates. J Toxicol Environ Health 3: 43

Hidy PH, Baldwin RS, Greasham RL, Keith CL, McMullen JR. 1977. Zearalenone and some derivatives: production and biological activities. Adv Appl Microbiol 22: 59-82

James LJ, Smith TK. 1982. Effect of dietary alfalfa on zearalenone toxicity and metabolism in rat and swine. J Anim Sci 55: 110-118.

Katzenellenbogen BS, Katzenellenbogen JA, Mordecai～D. 1979. Zearalenone: Characterization of the estrogenic potencies and receptor interactions of a series of fungal $\beta$-resorcylic acid lactones. Endocrinology 105: 33-40.

Zhu L, Yuan H, Guo C, Lu Y, Deng S, Yang Y, Wei Q, Wen L, He Z. 2011. Zearalenone induces apoptosis and necrosis in porcine granulosa cells via a caspase-3- and caspase-9-dependent mitochondrial signaling pathway. J Cell Physiol, DOI: $10.1002 /$ jcp. 22906
McNutt SH, Purwin P, Murray C. 1928. Vulvovaginitis in swine, Preliminary report. J Amer Vet Med Assoc 73: 484.

Mirocha CJ, Christensen CM, Nelson GH. 1967. Estrogenic metabolite produc ed by Fusarium graminearun in stored corn. Appl Microbiol 15: 497.

Mirocha CJ, Pathre SV, Schauerhamer B, Christensen CM. 1976. Natural occurrence of Fusarium toxins in feedstuff. Appl Environ Microbiol 32: $553-556$

Rodgers RJ, Irving-Rodgers HF. 2010. Morphological classification of bovine ovarian follicles. Reproduction 139 (2): 309-318.

Rugh R. 1968. The mouse - its reproduction and development. Burgess Publ. Co, Minneapolis.

Shank RC, Bourgeois CH, Keschamras N, Chandavimol P. 1971. Aflatoxin and autopsy specimens from Thai children an acute disease of unknown etiology. Food Cosmet Toxicol 9: 501-507.

Steel RGD, Toriie JH. 1981. Principles and procedures of statistics a biometrical approach. Mc Graw Hill Book Co. Singapore.

Stob M, Baldwin RS, Tuite J, Andrews FN, Gillette KG. 1962. Isolation of an anabolic, uterotrophic compound from corn infected with Gibberella zeae. Nature 196: 1318

Su YQ, Sugiura K, Eppig JJ. 2009. Mouse oocyte control of granulosa cell development and function: paracrine regulation of cumulus cell metabolism. Semin Reprod Med 27 (1): 32-42.

Sutasurya LA. 1985. The guidance of making permanent preparations. Department of Biology ITB, Bandung. [Indonesia]

Taylor P. 1986. Practical Teratology. Academic Press. London.

Ueno Y, Shimida N, Yagasaki S, Enomoto M. 1974. Toxicological approach to the metabolites of Fusaria: effects of zearalenone on the uteri of mice and rats. Chem Pharm Bull 22: 219-227.

Urry WH, Wehrmeister HL, Hodge EB, Hidy PH. 1966. The structure of zearalenone. Tetrahedron Lett (27): 3109.

Yasuda Y, Konishi H, Tanimura T. 1985. Gonadal dysgenesis induced by prenatal exposure to ethinyl estradiol in mice. Teratology 32: 219227.

Yasuda Y, Konishi H, Tanimura T. 1986. Leydig cell hyperplasia in fetal mice treated transplacentally with ethinyl estradiol. Teratology 33: 281-288. 